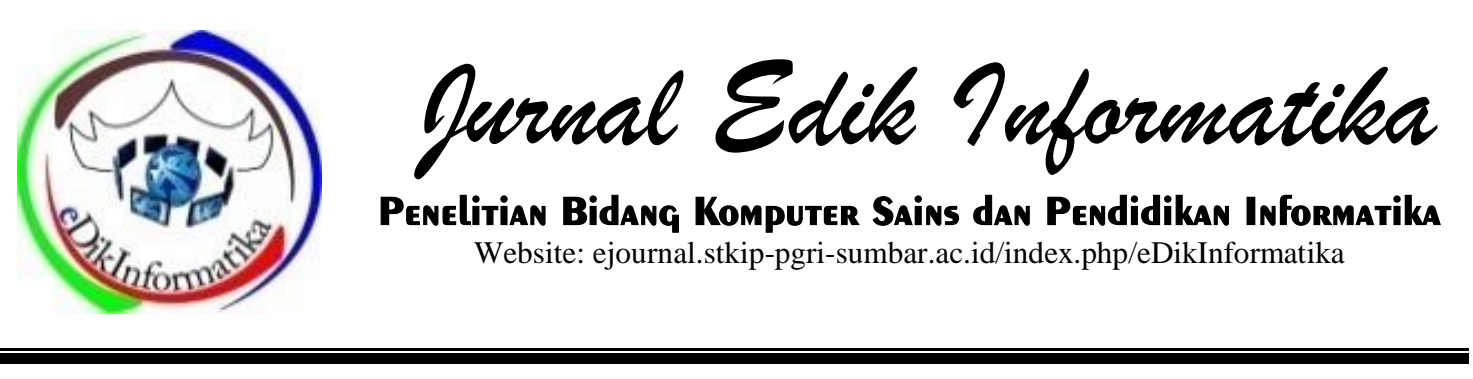

\title{
SISTEM INFORMASI PENGELOLAAN MASJID ONLINE MENGGUNAKAN METODE WATERFALL
}

\author{
Anjasmara $^{1}$, Linda Marlinda ${ }^{2}$, Ahmad Fauzi ${ }^{3}$ \\ ${ }_{1,2,3}$ STMIK Nusa Mandiri \\ anjasmarahermawan@gmail.com ${ }^{1}$, linda.ldm@nusamandiri.ac.id², ahmad.azy@nusamandiri.ac.id ${ }^{3}$
}

\begin{tabular}{l} 
INFO ARTIKEL \\
\hline Diterima: \\
04 Oktober 2019 \\
Direview: \\
05 November 2019 \\
Disetujui: \\
30 November 2019 \\
\hline
\end{tabular}

Keywords:

Web, Mosque,

Information

\begin{abstract}
The current management of mosque management is very much needed, especially for large mosques that have many activities as centers of worship and propaganda. Many large mosques in service to pilgrims still use manual methods, especially recitation information, pilgrimage discussions, donations and alms, Friday activities, Eid al-Fitr or Eid al-Adha and so on. Not only that but the documentation of financial statements also still uses ordinary notebooks. This is ineffective because it can result in poorly organized records that result in a lot of data being lost when the data is to be searched so it is difficult to make an accurate report. The solution to the problem must be supported by fast, accurate, and up-to-date information, so a web-based mosque information system needs to be prepared that can be accessed by worshipers and mosque administrators everywhere. The method used in this study uses the waterfall method through several stages of activities including data collection, observation, and interviews with the caretakers and worshipers of the mosque. The results obtained by the online-based mosque include information on the profile of the mosque, various mosque activities, mosque construction or renovation funds, a list of mosque administrators and a list of donors, both permanent and non-permanent. The web-based online mosque management information system enables the DKM to be more effective and efficient in terms of managing financial reports, delivering information to pilgrims, and can even be used as a means of receiving online donations.
\end{abstract}

\section{PENDAHULUAN}

Masjid merupakan tempat ibadah bagi umat islam, namun seiring dengan perkembangan jaman dan teknologi masjid saat ini bukan hanya berperan sebagai tempat ibadah saja. Banyak sekali tansaksi juga kegiatan yang saat ini dilakukan di masjid mulai dari kegiatan pembinaan, pendidikan, pembelajaran, pemberdayaan umat, pemotongan hewan 
kurban, kegiatan hari besar, bahkan sampai dengan acara resepsi pernikahan saat ini sering kali terjadi di masjid.

Masjid An-Nur Bekasi utara adalah salah satu masjid besar yang berada di Perumahan Villa mutiara gading 1 Desa setia asih tarumajaya Bekasi Utara.masjidAn-Nur belum memiliki sistem informasi dalam pengelolaan kegiatan dan keuangan masjid. Banyaknya kegiatan di masjid An-Nur, manajemen keuangan masjid yang belum tertata dengan baik, pengolahan data di masjid An-Nur yang manual, serta proses peminjaman masjid yang juga masih manual, menjadikan pengurus masjid kesulitan dalam dalam mengolah data dan membutuhkan waktu yang lama. Oleh Karena itu dibutuhkanlah sebuah Sistem terkomputerisasi yang dapat membantu permasalahan tersebut.

Berbagai macam peneletian telah dilakukan oleh banyak ahli. Welim \& Sakti (2017) berpendapat bahwa Pengelolaan dana masjid ataupun Yayasan adalah suatu kegiatan yang dilakukan oleh suatu organisasi, yang hampir setiap bulan dilakukan, demi memberikan informasi pemasukan maupun pengeluaran dana yang ada dalam Yayasan tersebut. Dengan sudah berkembangnya teknologi pada saat ini, maka organisasi yang ada di Masjid sudah bisa menggunakan sistem yang terkomputerisasi, karena sistem yang sudah terkomputerisasi mempunyai banyak dampak positif untuk setiap organisasi.

Menurut (Swara \& Hakim, 2016)Data dan informasi adalah sesuatu yang teramat penting dan berharga dalam sebuah organisasi dewasa ini. Pengelolan data dan informasi yang akurat dan cepat dapat membantu tumbuh kembangnya sebuah organisasi. Maka dari itu, pengelolaan data dan informasi dipandang penting demi kelancaran sebuah pekerjaan dan untuk menganalisa perkembangan dari pekerjaan itu sendiri. Untuk pengelolaan data dan informasi dibutuhkan sebuah sistem aplikasi terkomputerisasi. Sistem aplikasi juga sangat dibutuhkan dalam pengelolaan zakat pada Badan Amil Zakat (BAZ) Masjid seperti di Masjid Raya Andalas Padang. Adapun tujuan yang hendak dicapai dalam penulisan tugas akhir adalah menghasilkan sistem aplikasi pengolahan zakat berbasis web pada Masjid Raya Andalas Padang. Dengan adanya sistem aplikasi pengolahan zakat berbasis web pada Masjid Raya Andalas Padang dapat memperbaiki pengolahan data zakat Masjid Raya Andalas Padang serta dapat membantu Masjid Raya Andalas Padang dalam meningkatkan pelayanan kepada umat secara umum, dan kepada muzakki serta mustahik secara khususnya.

Menurut (Marlinda \& Hamid, 2014) Informasi adalah hasil pengolahan sehingga menjadi bentuk yang penting bagi penerimanya dan mempunyai kegunaan sebagai dasar dalam pengambilan keputusan yang dapat dirasakan akibatnya secara langsung saat itu juga atau secara tidak langsung pada saat mendatang.

Berdasarkan hal tersebut dapat disimpulkan untuk mengatasi masalah yang ada pada Mesjid An-Nur dibutuhkan sistem manajemen yang bisa diakses dengan mudah, kapan dan dimana saja oleh pengurus masjid serta memberikan informasi yang tepat, cepat dan akurat mengenai kegiatan maupun keuangan masjid An-Nur kepada masyarakat. Atas dasar tersebut dikembangkan sistem informasi manajemen masjid berbasis web.

\section{METODE PENELITIAN}

Peneliti menggunakan metode waterfall karena tahap demi tahap yang dilalui harus menunggu selesainyayang memiliki tahap-tahap sebagai berikut : 
Menurut Rosa \& Shalahuddin, (2018:28-30) "Model SDLC air terjun (waterfall) sering juga disebut model sekuensial linier (sequential linear) atau alur hidup klasik (classic life cycle).Model air terjun menyediakan pendekatan alur hidup perangkat lunak secara sekuensial atau terurut dimulai dari, analis, desain, pengkodean, pengujian dan tahap pendukung (support). Dengan berbagai kelemahan yang dimiliki model air terjuntapi model ini telah menjadi dasar dari model-model yang lain dalam melakukan perbaikan model pengembangan perangkat lunak".

\section{Teknik Pengumpulan Data :}

Teknik pengumpulan data yang digunakan dalam penelitian tugas akhir ini diantaranya adalah observasi, wawancara dan studi pustaka yang dijelaskan dibawah ini :

a. Observasi

Penulis melakukan penelitian langsung terhadap kegiatan pada untuk mengumpulkan data dan informasi yang berkaitan dengan permasalahan yang ada. Informasi yang berkaitan adalah proses jalannya sistem di Masjid An-nur Bekasi Utara.

b. Wawancara

Selama penelitian, penulis melakukan proses tanya jawab secara langsung mengenai hal-hal yang ada kaitannya dengan topik yang diambil kepada narasumber dalam obyek penelitian kepada 20 responden dari pengurus dan jamaah dengan 5 pertanyaan singkat.

c. Studi pustaka

Metode yang digunakan untuk mendapatkan informasi dari beberapa sumber seperti buku, jurnal, internet dan lainnya yang berkaitan dengan penelitian sebagai bahan referensi dalam menyusun penelitian ini menggunakan metode waterfall.

\section{Proses Bisnis Sistem}

1. Prosedur Pemberian Informasi

Sekretaris DKM membuat surat resmi yang berisi berita ataupun pengumuman terkini yang dikeluarkan oleh pihak masjid. Kemudian, sekretaris DKM menempel surat resmi tersebut di papan informasi. Lalu, jemaah masjid dapat melihat surat resmi yang telah terpampang di papan informasi tersebut. Dari surat resmi itulah, para jemaah bisa mendapatkan informasi mengenai berita ataupun pengumuman terkini yang dikeluarkan oleh pihak masjid.

2. Proses Pemberian Donasi

Apabila jemaah ingin memberikan donasi, jemaah dapat mendatangi masjid untuk menemui pihak DKM lalu memberikan donasi kepada bendahara DKM. Kemudian, bendahara DKM akan menerima donasi dari jemaah tersebut dan akan memberikan kwitansi. Selanjutnya, jemaah menerima kwitansi tersebut sebagai bukti bahwa donasi telah diterima oleh pihak masjid.

3. Proses Pembuatan Laporan Keuangan Setiap akhir bulan, bendahara membuat laporan keuangan masjid, yang isinya menjelaskan tentang berapa jumlah pemasukkan dan pengeluaran kas masjid selama satu bulan terakhir. Setelah selesai membuat laporan keuangan, bendahara mencetak laporan keuangan tersebut untuk diserahkan kepada ketua DKM. Selanjutnya, ketua DKM menerima laporan keuangan tersebut untuk mengetahui kondisi keuangan masjid selama satu bulan terakhir. 


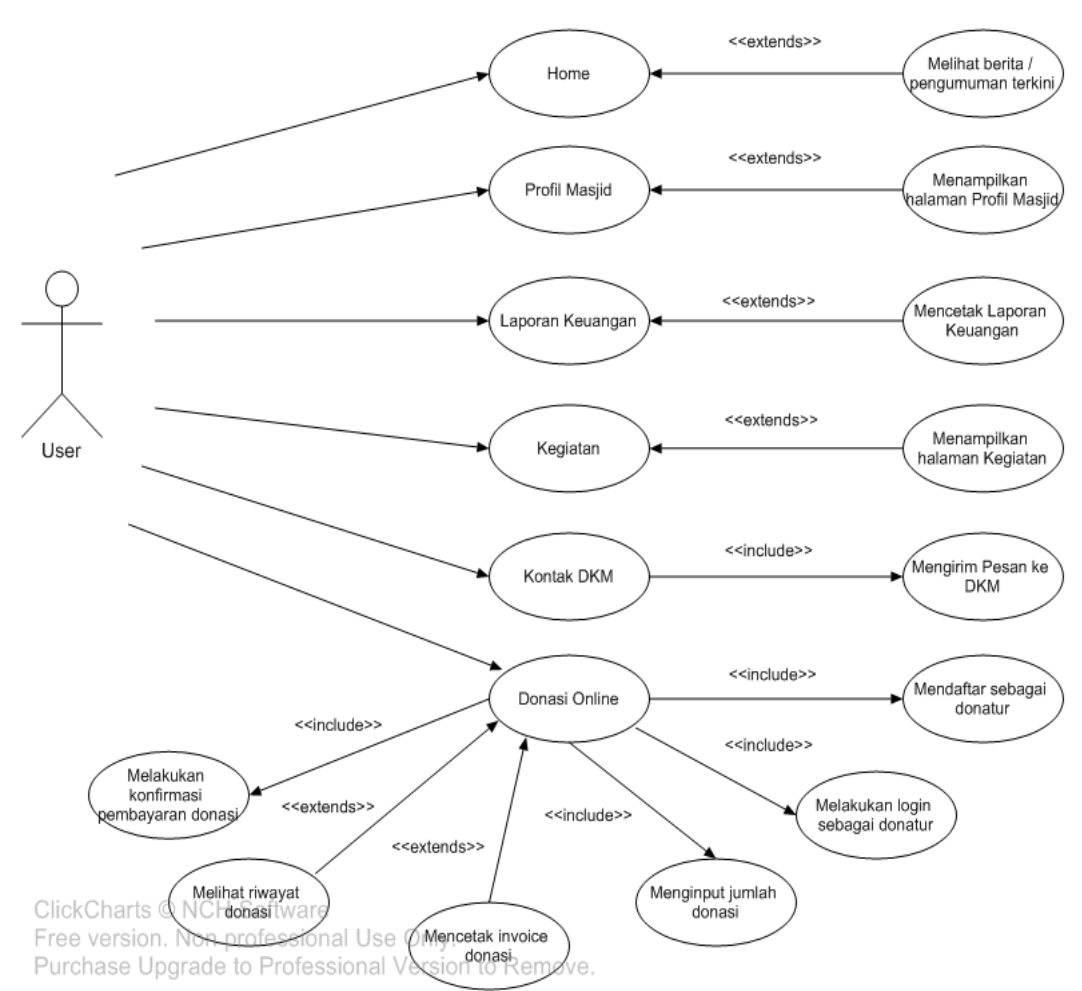

Gambar 1. Use case Diagram

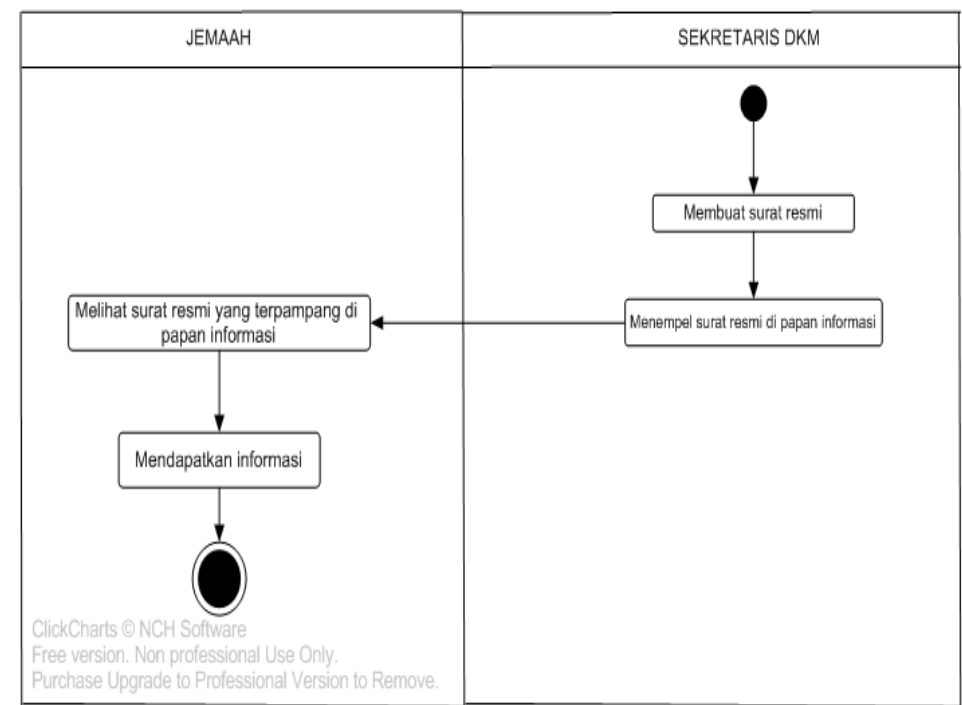

Gambar 2. Activity Diagram Pembuatan Laporan Keuangan

\section{Perancangan Sistem}

1. Use Case Diagram

Diagram usecase digunakan untuk mendeskripsikan apa yang seharusnya dilakukan oleh sistem. Gambar 1 merupakan Use Case Diagram Secara Detail Pada Masjid An-nur Bekasi Utara.
2. Activity Diagram

Diagram Aktivitas memperlihatkan alur aktivitas yang berjalan pada Sistem. Diagram Activity dapat dilihat pada gambar 2 dan gambar 3. 


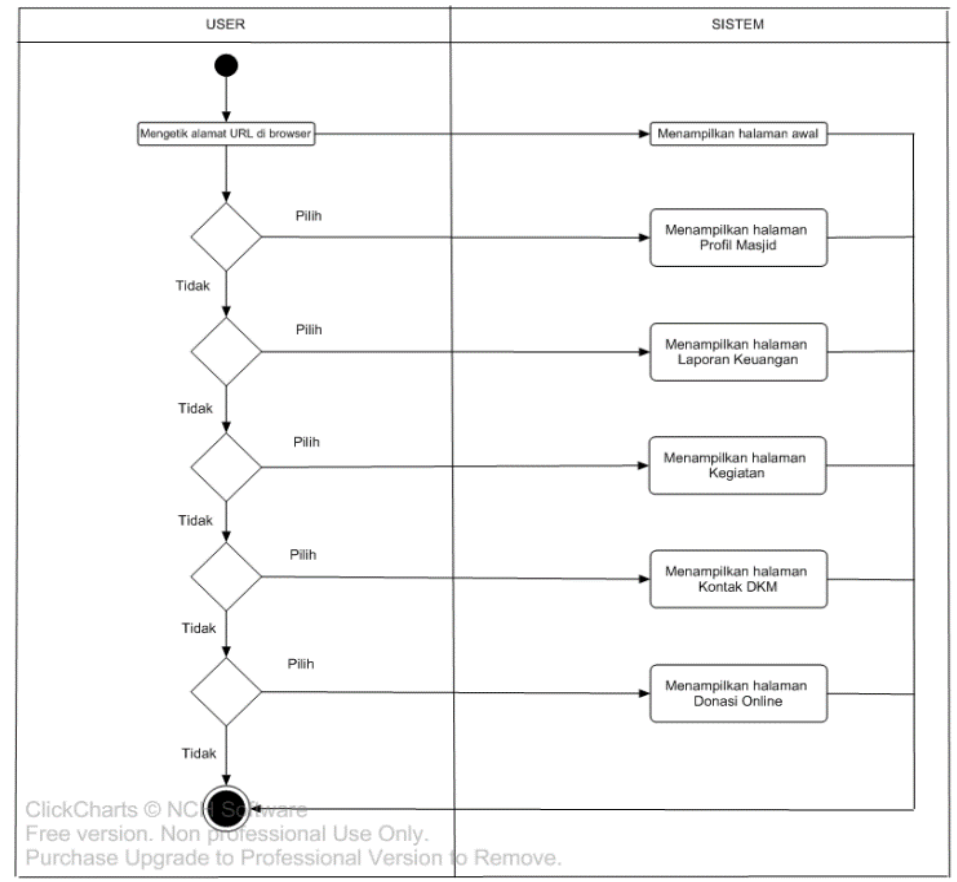

Gambar 3. Activity Diagram

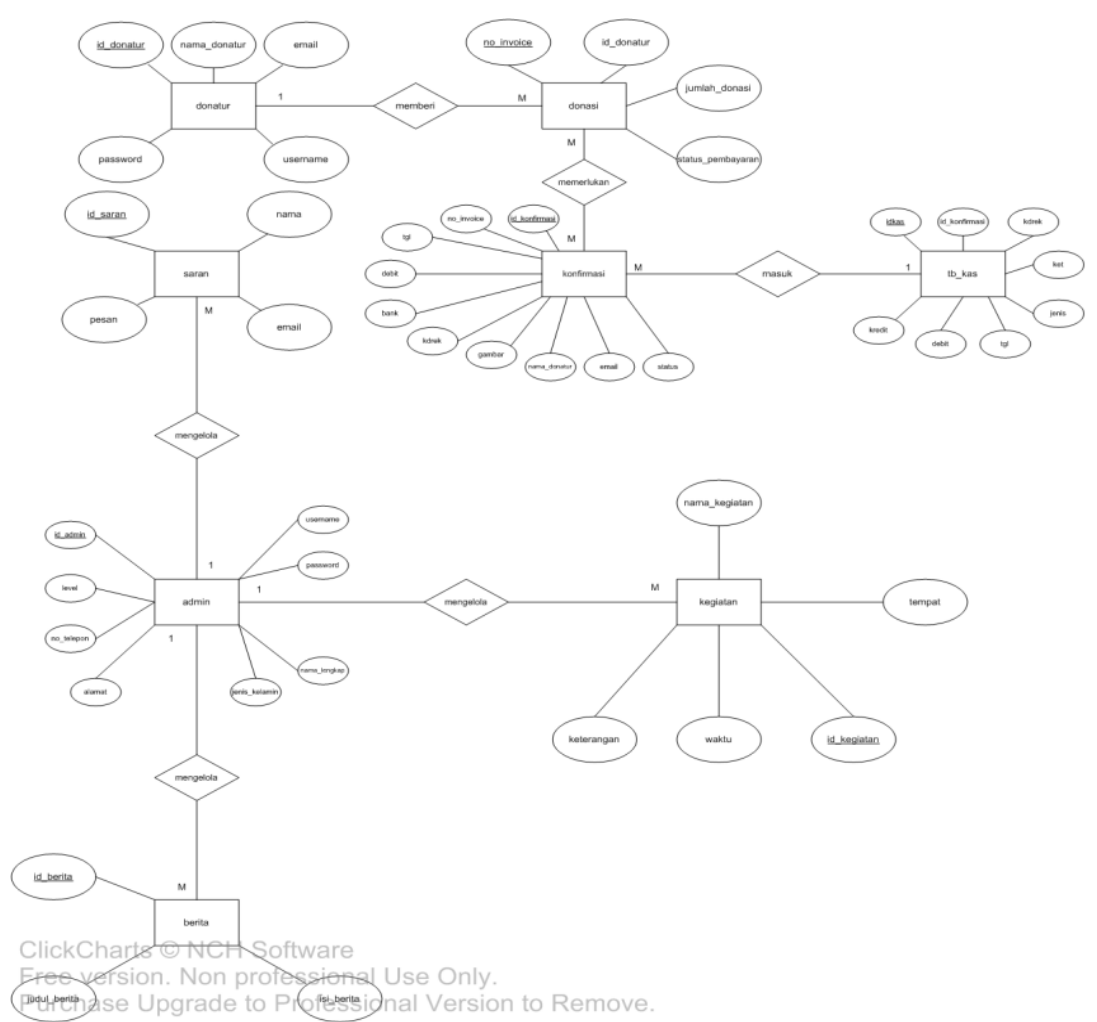

Gambar 4. Relationship Diagram

3. Relationship Diagram

Pada tahap ini penulis akan menjelaskan tentang hubungan antar tabel yang ada pada website yang meliputi Entity Relationship Diagram dan spesifikasi file. Relationship diagram Sistemte 
masjid An-Nur dapat dilihat pada gambar 4.

\section{HASIL DAN PEMBAHASAN}

\section{User Interface}

\section{Tampilan Halaman Website}

Halaman home merupakan halaman yang pertama kali ditemui ketika pengunjung mengakses situs internet ini.

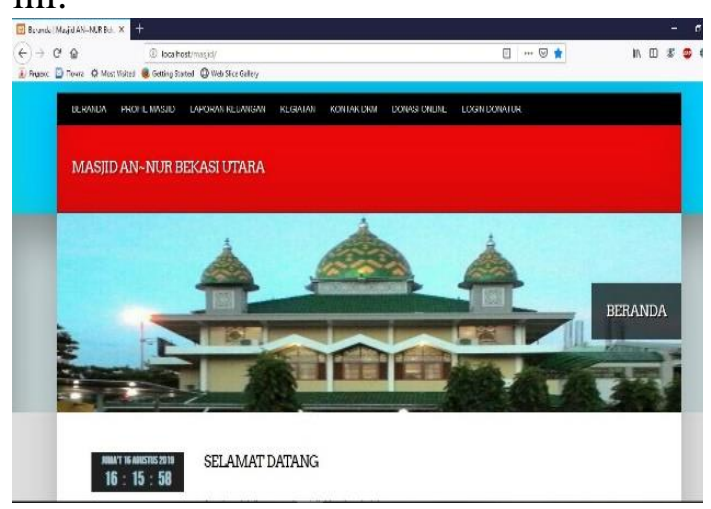

Gambar 5. Tampilan Halaman Awal

\section{Hasil Uji Coba Sistem}

Pada saat peneliti melakukan riset menggunakan media kuesioner dan wawancara untuk mengetahui apakah penelitian ini bermanfaat atau diinginkan oleh DKM\&Jamaah Masjid khususnya dengan jumlah 20 responden dengan 5 pertanyaan yang berkaitan langsung dengan penelitian. Hasil pengamatan penggunaan web masjid online pembelajaran dapat dilihat pada tabel 1 .

Kuesioner menggunakan skala Likert lima item, terdiri dari sikap Sangat Setuju (SS), Setuju (S), Ragu-ragu (R), Tidak Setuju (TS), Sangat Tidak Setuju (STS).

Hasil kuesioner tersebut diolah dengan menggunakan SPSS metode Bivariate Pearson (korelasi produk momen pearson) adalah analisis dengan cara mengorelasi masing - masing skor item dengan skor total. Hasil pengujian berdasarkan isian responden dapat dilihat pada tabel 2 .

Tabel 1 Skor Pengujian

\begin{tabular}{|l|l|l|l|l|l|l|}
\hline \multirow{2}{*}{$\begin{array}{l}\text { Responde } \\
\text { n }\end{array}$} & \multicolumn{7}{|c|}{ Skor Pertanyaan } & \multirow{2}{*}{ Skor Total } \\
\cline { 2 - 6 } & $\mathbf{1}$ & $\mathbf{2}$ & $\mathbf{3}$ & $\mathbf{4}$ & $\mathbf{5}$ & \\
\hline 1 & 5 & 3 & 5 & 3 & 5 & 21 \\
\hline 2 & 6 & 5 & 5 & 4 & 3 & 23 \\
\hline 3 & 4 & 3 & 2 & 4 & 3 & 16 \\
\hline 4 & 3 & 4 & 3 & 4 & 2 & 16 \\
\hline 5 & 4 & 2 & 4 & 3 & 4 & 17 \\
\hline 6 & 3 & 4 & 3 & 4 & 4 & 18 \\
\hline 7 & 4 & 4 & 4 & 4 & 4 & 20 \\
\hline 8 & 2 & 3 & 4 & 3 & 4 & 16 \\
\hline 9 & 3 & 3 & 3 & 4 & 2 & 15 \\
\hline 10 & 4 & 4 & 2 & 4 & 3 & 17 \\
\hline 11 & 5 & 3 & 7 & 4 & 2 & 21 \\
\hline 12 & 3 & 5 & 4 & 6 & 7 & 25 \\
\hline 13 & 2 & 7 & 5 & 4 & 1 & 19 \\
\hline 14 & 4 & 6 & 5 & 6 & 3 & 24 \\
\hline
\end{tabular}




\begin{tabular}{|l|l|l|l|l|l|l|}
\hline 15 & 7 & 7 & 4 & 3 & 2 & 23 \\
\hline 16 & 4 & 4 & 3 & 5 & 4 & 20 \\
\hline 17 & 3 & 5 & 4 & 3 & 2 & 17 \\
\hline 18 & 4 & 4 & 4 & 4 & 4 & 20 \\
\hline 19 & 5 & 7 & 6 & 4 & 3 & 25 \\
\hline 20 & 4 & 4 & 2 & 4 & 7 & 21 \\
\hline Jumlah & 64 & 87 & 80 & 80 & 66 & 377 \\
\hline
\end{tabular}

Tabel 2 Hasil Pengujian

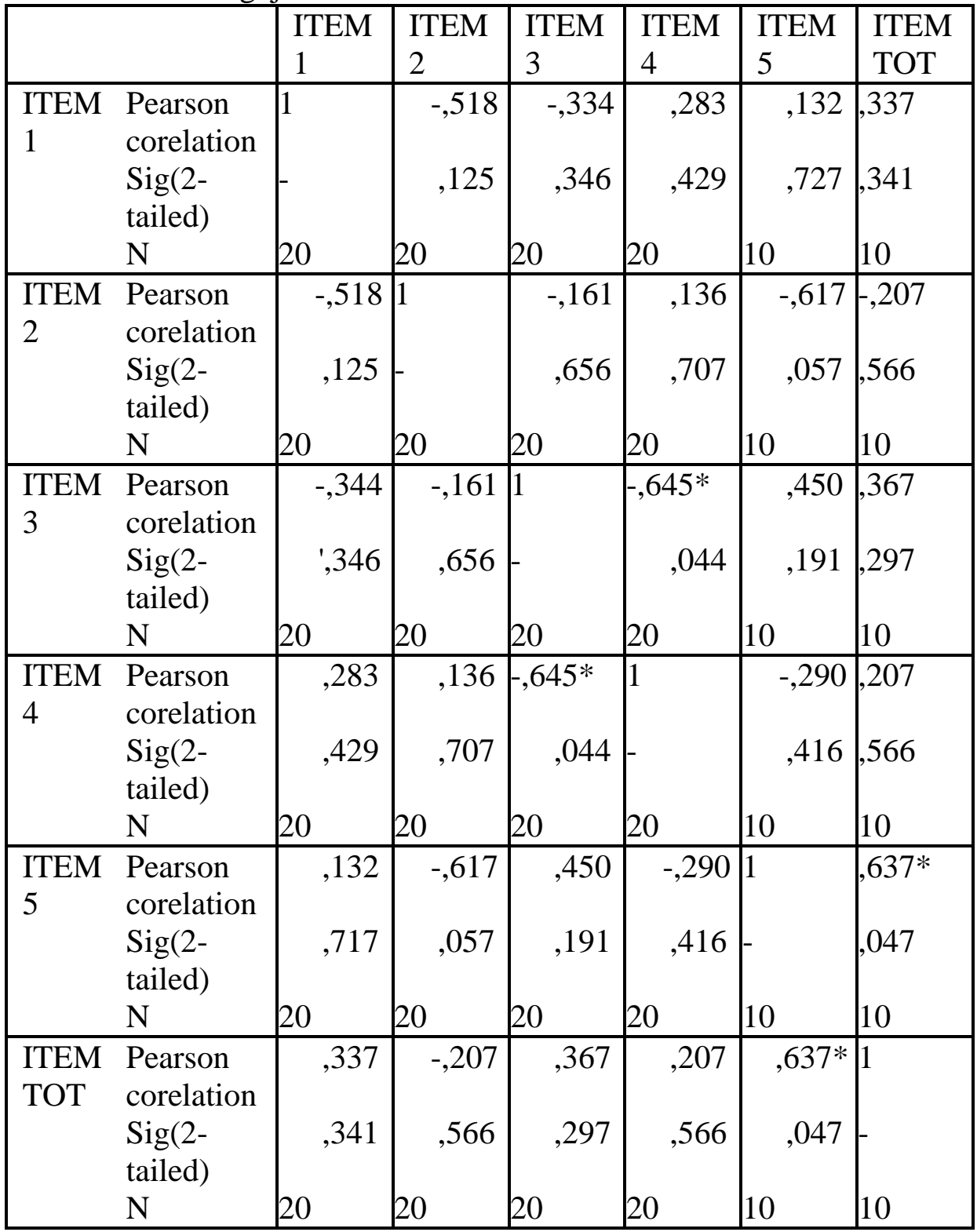

Dari tabel 1 dan table 2 dapat diketahui bahwa hampir semua pernyataan memperoleh respon positif (Setuju dan Sangat Setuju). Hal ini 
diketahui dari modus dan median yang terletak pada jawaban S (Setuju).

\section{KESIMPULAN}

1. Dengan mengaplikasikan sistem informasi pengelolaan, Masjid AnNur Bekasi Utara dapat menyampaikan kegiatan, berita, serta pengumuman terkini kepada jemaah secara efektif dan efisien.

2. Memberikan kemudahan bagi jemaah untuk dapat memperoleh informasi secara jelas mengenai kegiatan, berita, serta pengumuman terkini yang dikeluarkan oleh pihak DKM masjid.

3. Terdapat sarana bagi para jemaah untuk melakukan donasi secara online.

\section{DAFTAR PUSTAKA}

Novryaldy, A., \&Seitadi, T. (2018). Perancangan Sistem Informasi Profil Masjid Berbasis Website. Jurnal Ilmiah Teknologi Infomasi Terapan, 4(3), 242-252.

Https://Doi.Org/10.33197/Jitter.Vol 4.Iss3.2018.172.

Rosita Andarsari, P. (2016). Laporan Keuangan Organisasi Nirlaba (Lembaga Masjid). Jurnal Ekonomi Universitas Kadiri, 143-152.

Rusmawan, U. (2019). Teknik Penulisan Tugas Akhir Dan Skripsi Pemrograman. Jakarta: PT Elex Media Komputindo.

Swara, G. Y., \&Hakim, D. (2016). Perancangan Sistem Aplikasi Pengolahan Zakat Berbasis Web ( Studi Kasus: Badan Amil Zakat Masjid Raya Andalas Kota Padang ). Jurnal TEKNOIF, 4(1), 32-39.

Welim, Y. Y., \&Sakti, A. R. (2017). Rancang Bangun Sistem Informasi Administrasi Pengelolaan Dana
Masjid Pada Yayasan Al-Muhajiriin, Tangerang. Simetris : Jurnal Teknik Mesin, Elektro Dan Ilmu Komputer, 7(1), Https://Doi.Org/10.24176/Simet.V7i $\underline{1.485}$

Rosa, A. ., \&Shalahuddin, M. (2018). Rekayasa Perangkat Lunak Terstruktur Dan Berorientasi Objek. Bandung: Informatika Bandung. Marlinda, L., Rianto, H., Informatika, M., Bina, A., \&Informatika, S.

[1].(2013). Pembelajaran Bahasa Indonesia Berbasis Web. 2-4. 